\title{
Construction of an open innovation network and its mechanism design for manufacturing enterprises: a resource- based perspective
}

Haijun Wang ${ }^{1,2^{*}}$ and Sardar M. N. Islam²

\section{* Correspondence:} wanghj77@163.com

'School of Management, Shenyang University of Technology, Shenyang 110870, China

${ }^{2}$ Decision Sciences and Modelling Program, Victoria University, Victoria 8001, Australia

\section{Abstract}

Innovation is the engine of development for enterprises, and there is an increasing trend to adopt an open innovation strategy. However, how to manage external resources in an open, collaborative and complementary manner, and in a shared environment that will yield the greatest networking effects, it is a challenging task. Because there is no such a satisfactory model for an open innovation strategy that combine operational mechanisms with the management of, external resources. Thhis article tries to fill the gap by adopting a resource-based perspective to construct an overall open innovation (OOI) business model. In this model, external resources are classified as industrial and non-industrial entities, to enable the identification of the interaction methods between manufacturing enterprises and external resources. The management of external resources involved in a Technology Open Innovation (TOI) cycle is given particular attention that includes: 1) the classification of the external resources of a TOI, 2) the general mechanisms extracted to promote qualified resources in and unqualified resources out, and 3) a business model to conceptualize the collaboration between enterprises and external resources. A case study of TOI is also provided to empirically verify its feasibility. This paper contributes to the literature by providing an original operational model and mechanism design for an open innovation strategy that is capable of managing external resources effectively.

Keywords: Manufacturing enterprise, Open innovation, Resource dependence, External resources, Mechanism

\section{Introduction}

With the advent of the internet age, manufacturing enterprises face new challenges and opportunities in the competitive globalized local and global market. Driven by the rapid development of market globalization, manufacturing enterprises must make greater efforts to fulfil individual demands from the market by utilizing global resources and through open innovation. Since (Chesbrough 2003) first presented the concept of open innovation, the study of open innovation has become increasingly popular amongst academics and practitioners alike. Open innovation is defined as the process of strengthening the interaction and collaboration of multiple partners involved in a business ecosystem, to jointly deliver an innovative product or solution.

(c) The Author(s). 2017 Open Access This article is distributed under the terms of the Creative Commons Attribution 4.0 International License (http://creativecommons.org/licenses/by/4.0/), which permits unrestricted use, distribution, and reproduction in any medium, provided you give appropriate credit to the original author(s) and the source, provide a link to the Creative Commons license, and indicate if changes were made. 
This means that successful open innovation partnerships will be useful for exploring meaningful and innovative solutions to satisfy customers' requirements. Moreover, the sourcing, integration and development of products and business model innovations through "win-win" external partnerships are of great interest to manufacturing enterprises, to capture the maximum commercial value of their investments (Muhdi 2011; Nakagaki et al. 2012).

At present, a large number of manufacturing enterprises from different industries, such as consumer goods, electronics, and equipment have benefited greatly from the adoption of open innovation strategies to enrich their internal innovation processes (Serrono and Fischer 2007). Many of these companies compete to win through the implementation of an open innovation strategy, cooperating with various partners in a value chain-including universities and institutes, and even other enterprises-by flexibly opening up to external partnerships and placing increasingly reliance on their collaborations with external resources (Etzkowita 2008; Leydesdorff 2003). A good case in point is Procter \& Gamble's innovation practice (Huston and Sakkab 2006), whose success is attributed largely to innovative collaborations with external partners, whereby roughly $50 \%$ of Procter \& Gamble's new products now originate from outside the parent company. Classifying innovative resources and integrating them into an open innovation strategy has generally been considered too complicated a problem for manufacturing enterprises, and hence, this issue has not been adequately studied.

Therefore, the objective of this paper is to develop a new model for open innovation. The research questions of this paper consist of (1) what types of external resources could be identified to facilitate the development of open innovation? (2) what sort of business model is needed to develop the collaboration between manufacturing enterprises and external resources during an open innovation process? (3) how can a manufacturing enterprise adopt a certain mechanism to manage those external resources effectively?

This research makes several contributions to improve the modelling of an open innovation strategy that can enhance the innovative capabilities of manufacturing enterprises based on the existing research. First, a novel overall open innovation model is constructed. Second, the technology open innovation cycle is discussed, including the array of external resources and mechanisms to manage the external resources, and a business model in conjunction with a case study is presented.

This paper is structured as follows: Critical literature review and motivation for the study section discusses the research background and the motivation for the present study; Theoretical foundation of an open innovation strategy section provides a theoretical foundation for the proposed open innovation strategy. In Open innovation business model section, a business model for the overall open innovation is presented; while in Management of external resources in an open innovation system section, external resources are firstly classified and the mechanisms used to manage these external resources are then detailed. A business collaboration model of open innovation technology is discussed in A business collaboration model of the TOI section. A case study section presents a case study, focusing on the open innovation practice of a typical Chinese manufacturing enterprise. The conclusions of the study are presented in Conclusion section. 


\section{Critical literature review and motivation for the study}

Open innovation is defined as any interaction and collaboration between a manufacturing enterprise and its external resources. The pioneering open innovation perspective indicates that open systems are currently more applicable than closed systems. (Chesbrough 2003) suggests that closed innovation features no contact with any external environment until the product developed by the closed innovation system eventually becomes no longer sustainable, and requires upgrading support from external resources. Moreover, Chesbrough et al. (2014) describes the case study of Chez Panisse implementing an open innovation strategy with stakeholders, in particular, how the enterprise built a global ecosystem that shares knowledge, encourages individuals' growth, and embeds trust among participants. Because a new product development is a process that links technology and customers' needs (Dougherty 1992), it is necessary to unify the knowledge related to both the technology and the customers. As far as we understand, open innovation activities occur at various lifecycle phases of products and vary with regards to their content, the risk involved in developing and manufacturing marketable products, and in the speed of bringing such products to the market (Nambisan and Sawhney 2007). Therefore, since marketplace dynamics have led to an increased interest in the "open innovation" paradigm; enterprises are driven to accelerate their internal innovations with the help of external resources (Chesbrough 2007).

Following Chesbrough's contributions, there has been an increase in the literature on open innovation; and in some of these works, scholars have analyzed the influence of an enterprise's R\&D capacity on its motive to open up its innovation system (Todorova and Durisin 2007). This indicates that an enterprise's internal capabilities always determine the extent to which it opens up its innovation system and that enterprises with higher R\&D capabilities are more receptive to external resources (Zhou and Wu 2010). Additionally, when it comes to looking for external resources, these enterprises are more proactive, when compared to enterprises with lower R\&D capacities. In contrast, enterprises without such capacity have been hindered by their circumstances, and have failed to open their innovation systems to external resources (Rothaermel and Alexandre 2009). The results also indicate that the more innovative firms tend to be more interested in collaborating with universities and research institutes. According to Etzkowitz and Leydesdorff's triple-helix model (2008; 2003), a university normally concentrates on the study and dissemination of scientific and technological knowledge which is vital for industrial innovation. Moving forward, university-industry relationships under an open innovation scenario are further studied (Ivascu et al. 2016; Minshall et al. 2016), which helps answer how industries collaborate with universities to deal with problems that cannot be solved individually. Nevertheless, external resources and enterprises often have different perceptions pertaining to certain aspects of collaboration, which can lead to a lack of confidence and communication problems.

In recent years, communication between various businesses/enterprises and those undertaking academic studies have gradually extended the scope of open innovation. IBM reportedly opened a supply chain innovation center in China (IBM Press Room, 2008), collaborating with companies to develop new supply chain solutions. Meanwhile, the center also showcases and leverages existing 
industry solutions to help companies expand and grow their integrated supply chain capabilities. (Sakamoto et al. 2012) discusses the use of open innovation and collaborative networks as a resource to create value and increase competitiveness in the supply chain. (Nelli 2013) studies the adoption of open innovation practices during different value chain activities, and measures their effects on the product and innovation processes of small and medium-sized manufacturing companies, which expand the scope of open innovation beyond the focus of research and development. A supplier is regarded as an important source of external resources to accelerate open innovation. In particular, Early Supplier Involvement (ESI) is regarded as a form of vertical collaboration between the supply chain partners, in which a manufacturing enterprise integrates a supplier, with a qualified proven performance history (defined as the strategic supplier in this article), at an early stage of the New Product Development (NPD) process (Mikkola and Skjøtt-Larsen 2006). Moreover, the supplier, by being involved at the early stage of the R\&D process, can bring useful knowledge about how to improve the new product's quality, facilitate its manufacturability, or suggest ideas that strengthen the performance of the NPD process (Sivadas and Dwyer 2000; Zhao and Lavin 2012).

As far as the management mechanism for external resources is concerned, (Zhang and Chen 2008) presents a resource management framework and suggests that resources with innovative capacities be maintained and updated dynamically to help create an innovation resource pool. Scholars have suggested that a future research agenda should delve into enterprises' incentives to exchange knowledge (Erden et al. 2012; West et al. 2006). In particular, Gambardella and Panico (Gambardella and Panico 2014) shows that these incentives can be restored by empowering the weaker party to make decisions during the research process, and a stylized model has been presented to formalize open innovation. In addition, he studies the governance of collaboration, particularly how the parties allocate property rights, and the rights to make decisions during the research process. Regarding the mechanism design for the management of suppliers, (Laffont and Tirole 1988) presents the pioneering incentive contract theory, and suggests that it is necessary for a manufacturer to check the capability of a supplier to break the supplier's deliberate self-protection and avoidance of responsibility. Moreover, (Laffont and Tirole 1993) points out that a quality guarantee deposit or penalty could be asked for, to reinforce the constraint function towards suppliers. In many situations, suppliers are not able to satisfy manufacturers' demands due to shortages of materials, key parts and so on. Hence, capacity allocation mechanisms are proposed, to deal with the gap between suppliers' capacities and customers' demands (Cachon and Lariviere 1999a, b).

Despite a growing interest in the study of open innovation, the existing studies have some limitations, such as concentrating largely on either the R\&D or the supply chain stage. Moreover, there is a scarcity of effective evidence supporting the management of external resources to fuel manufacturing enterprises' innovativeness. The objective of this paper is to explore open innovation in a broad scope based on a new model, using empirical studies to explore the mechanism for managing external resources. Therefore, this paper makes a good contribution to the literature on open innovation strategy. 


\section{Theoretical foundation of an open innovation strategy \\ Resource dependence theory}

Resource Dependence Theory (RDT) has become one of the most influential theories in organizational theory and strategic management. The need for external resources, mainly covering funding, human resources, materials and information, makes organizations potentially dependent on their external resources. RDT characterizes a corporation as an open system, dependent on contingencies in the external environment (Pfeffer and Salancik 1978). RDT recognizes the influence of external factors on organizational behaviour, and although constrained by the context, executives can react to reduce any environmental uncertainty or dependency. In particular, the behaviour of the external resources will be constrained, so that they correspond to organizational effectiveness and the organizational environment, which is similar to the control over vital resources (Ulrich and Barney 1984). Given that organizations are not autonomous, as they are constrained by a network of interdependencies with other organizations, the external control of organizations shows them as being embedded in networks of interdependencies and social relationships (Granovetter 1985; Pfeffer 1987).

This paper constructs its model of an open innovation network based on RDT, in which, typically, the dependency relationship between industry and university can be explained as follows: since manufacturing enterprises form the core of the industry, they may obtain the necessary talent they require with relatively low costs from open innovation. More importantly, universities can participate in innovation activities based on their fundamental research advantages, since these are rarely carried out by manufacturing enterprises. In the future, the profitability of enterprises depends on their capability in obtaining innovative resources and transforming them into something of commercial value (Chesbrough et al. 2006). Conversely, universities need inputs from the industry to compensate for their lack of actual resources, due to their reliance on government funding in the past. Accordingly, universities need to comply with market logic and proactively link with enterprises for their sustainable development. By joining in the innovation loop, universities can obtain the application value for their knowledge, which in turn brings benefits for their forthcoming innovation research work.

\section{Innovation ecosystem theory}

Successful businesses are those that evolve rapidly and effectively, and they must attract resources of all types, drawing in capital, partners, suppliers, and customers to create cooperative networks (Moore 1993). By studying the co-evolution of social and economic systems, especially in a changing competitive context, Moore presented the business ecosystem concept, which is regarded as a dynamic network of organizations featuring mutual support among its members, who co-evolve their capabilities and roles around innovation and work cooperatively to create additional value and improve efficiency. Moving forward, (Li et al. 2014) combine the business ecosystem concept with innovation theory, and argue that the innovation ecosystem has become a new paradigm (innovation 3.0). 
Differing from the conventional innovation organization, network or alliance, the innovation ecosystem has the following typical features:

(1) Core role of the leading firm: The responsibilities of the leading firm in an innovation network consist of harmonizing the innovation objective/vision for the other members, steering the development of the innovation ecosystem and being responsible for the operational mechanism (Williamson and Meyer 2012). In addition, the leading firm also has an obligation to bridge the innovative outcomes with customers' requirements, and distribute any benefits to the members in the innovation ecosystem, based on their inputs.

(2) The winner-take-all logic is challenged: The innovation ecosystem is characterized by its openness to the public, which means that the differentiation of resources and complementary innovations are pursued. In the innovation ecosystem, members make use of their complementary advantages to push the innovation. Meanwhile, they are able to share resources in the innovation ecosystem to reach a "win-win" result based on efficient interactions and internal benign competition. The more qualified the innovation participants are who join in the ecosystem, the more value is generated that fits customers' requirements.

(3) Self-organization and co-evolution of an innovation ecosystem: Being a network composed of multiple stakeholders, the innovation ecosystem features selforganization, and co-evolution could enable an innovation strategy to shift from simple cooperation to collaborative innovation (Eisenhardt and Martin 2000). Moreover, the independent development of individuals gradually transforms into the co-evolution of the group. In this regard, there should be some mechanisms to ensure healthy operation of the innovation ecosystem. For instance, qualified resources may have access to the ecosystem while un-qualified ones have no opportunity to join in the innovation activity.

\section{Open innovation business model}

In this paper, we specify that Overall Open Innovation (OOI) should refer to a model whereby all the different parts of an enterprise involve themselves in innovation activities with external resources, to jointly meet customers' requirements. In this regard, we have enlarged the scope of open innovation to include the whole end-to-end chain of a manufacturing enterprise including marketing, R\&D, testing, sourcing manufacturing, after-sales, etc., in which corresponding departments have various innovation requirements driven by the manufacturing enterprise's business strategy.

Naturally, the above chain tends to integrate external resources in conjunction with their detailed requirements based on corporate external resource platforms. Based on the above-mentioned resource dependence theory and innovation ecosystem theory, an OOI business model is presented here to describe the logical relationship between manufacturing enterprises (shown in Fig. 1), end-users and external resources. The core manufacturing enterprise plays the dominant role in acquiring and analyzing the requirements of end-users; and it then integrates the relevant external resources to deliver the right service/product to satisfy end-users. In order to ensure that only qualified external resources are in the innovation loop, certain mechanisms for managing external resources are built and executed, which accordingly form a self-rotating 


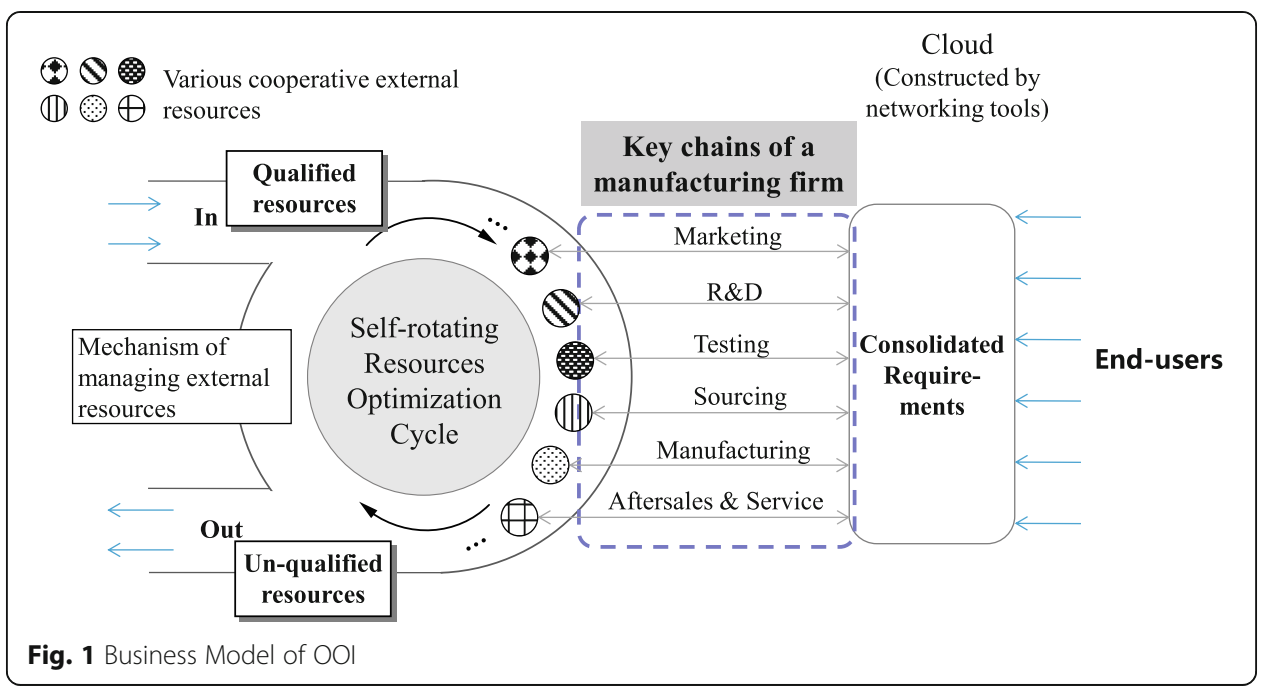

resources optimization cycle. In this cycle, various external resources operate dynamically, corresponding to their nature, to combine the relevant requirements of the manufacturing enterprise's business chains. In this regard, an open innovative ecosystem constituted by different innovative participants and mechanisms can be created. In this ecosystem, innovative participants collaborate with each other to create user value as the core. Meanwhile, they share information dynamically through in-time interactions during the process of innovation. In the internet age, networking tools constructing Clouds are effective for in-time information communication between manufacturing enterprises, external resources and end-users when carrying out open innovations.

\section{Management of external resources in an open innovation system}

\section{External resources classification}

Technology Open Innovation (TOI) refers to the innovative technological research and new product development undertaken to satisfy customers' requirements, and competitive technological creations that pave the way for product marketability. This is the core that both the enterprises and external resources seek to contribute to. A TOI aims to produce competitive and marketable products through joint research and development. Normally, the external resources involved in a TOI come from various areas, each of them bringing an individual capacity that may aid the manufacturing enterprise when steering the innovation project. During the course of an innovation project, the manufacturing enterprise has various requirements, such as knowledge, technology, inspections, management, venture capital, consultation, and the supply of materials/components, which means that the inputs from the external resources need to be in line with the actual requirements at different stages of the TOI (concept \& definitions, project planning, design, prototype engineering, testing, etc.). The external resources are classified below. Besides the core manufacturing enterprise in an open innovation network, we classify the external resources into industrial entities and non-industrial entities as follows:

(1) Industrial entity: Those external resources classified as an industrial entity are dedicated to helping the core manufacturing enterprise promote the 
industrialization of innovative technologies, including their development, testing, production and marketing promotion, etc. The external resources of an industrial entity mainly cover suppliers, partner enterprises, small firms capitalized by the enterprise, testing/certification institutions, industrialization agents, etc. As defined above, a strategic supplier ${ }^{1}$ plays a vital role in open innovation, which is indispensable nowadays for technological innovation and product upgrading of enterprises. Strategic suppliers not only supply components but also bring unique R\&D capacities to the enterprise, and they may also have the ability to manage normal suppliers.

(2) Non-industrial entity: Its roles in open innovation include individual feedback/ inputs, basic research, technology research and development, industry standards development and market competition supervision, etc. Non-industrial entities include individuals, universities, research institutions, consulting firms, law firms/IP management agencies, industrial associations and standardization committees, governments, etc.

More importantly, strategic suppliers with proven capacities are also indispensable for their involvement in the early stages of a TOI. The benefit of this early connection with strategic suppliers is that the enterprise gains access to and can utilize their technological, production and inspection capacities to combine R\&D innovations with the supply chain. In our study, the commercialization of open innovation findings is exceedingly difficult to realize substantially without the assistance of a supply chain.

The cooperation between the core manufacturing enterprise and its external resources is diverse. For example, suppliers are not limited to the supply of materials or components for the manufacturing enterprise, but they can also rely on their innovative technology to get involved in the open innovation process; in this case, both sides are expected to engage in strategic collaborations. As far as universities and research institutions are concerned, they can carry out fundamental research and joint development of technology respectively, on terms specified by the core manufacturing enterprise. Additionally, it is essential for any manufacturing enterprise and university to carry out talent training projects together, while scholars or experts from academia/the university can be hired by the manufacturing enterprise to strengthen cooperation with each other (shown in Table 1).

\section{Mechanism design for external resources}

In order to integrate the above-mentioned external resources to reinforce the TOI, it is essential to design a corresponding general mechanism so that qualified resources can be screened, and to allow for collaborative and innovative relationships between the manufacturing enterprise and its external resources to be maintained, and also to enable the achievement of the expected innovation targets. Otherwise, the overall collaborative work between the different participants would occur randomly because the management of the external resources is not orderly.

\section{Searching for external resources}

On the one hand, manufacturing enterprises can establish an external collaborative platform as a major outlet for requests of distribution and collection. On the other 
Table 1 Interaction methods during open innovation between a manufacturing enterprise and external resources

\begin{tabular}{|c|c|c|c|c|}
\hline \multirow{2}{*}{$\begin{array}{l}\text { Center of open } \\
\text { innovation }\end{array}$} & \multicolumn{3}{|c|}{ External resources } & \multirow{2}{*}{$\begin{array}{l}\text { Interaction methods } \\
\text { during the open } \\
\text { innovation process }\end{array}$} \\
\hline & Category & Functionality & Major resources & \\
\hline \multirow[t]{14}{*}{$\begin{array}{l}\text { Manufacturing } \\
\text { enterprise }\end{array}$} & \multirow[t]{6}{*}{$\begin{array}{l}\text { Industrial } \\
\text { entity }\end{array}$} & \multirow{6}{*}{$\begin{array}{l}\text { To provide services for the } \\
\text { core manufacturing enterprise } \\
\text { related to the industrialization } \\
\text { stage of the open innovation } \\
\text { process, such as engineering \& } \\
\text { design ideas, material supply, } \\
\text { testing, etc. }\end{array}$} & Supplier & $\begin{array}{l}\text { Strategic collaboration } \\
\text { and Early Supplier } \\
\text { Involvement (ESI) in } \\
\text { the R\&D stage }\end{array}$ \\
\hline & & & $\begin{array}{l}\text { Partner } \\
\text { enterprise }\end{array}$ & $\begin{array}{l}\text { Set up joint-venture or } \\
\text { project and develop } \\
\text { innovative technology/ } \\
\text { product }\end{array}$ \\
\hline & & & $\begin{array}{l}\text { Small firm } \\
\text { (capitalized } \\
\text { by the } \\
\text { manufacturing } \\
\text { enterprise) }\end{array}$ & $\begin{array}{l}\text { Allocated research } \\
\text { and development }\end{array}$ \\
\hline & & & Testing labs & $\begin{array}{l}\text { Allocated testing and } \\
\text { certification work for } \\
\text { testing labs, or set up } \\
\text { joint labs }\end{array}$ \\
\hline & & & $\begin{array}{l}\text { Industrialization } \\
\text { agent }\end{array}$ & $\begin{array}{l}\text { Venture Capital (VC) or } \\
\text { Direct Capital (DC) to } \\
\text { promote the } \\
\text { industrialization of the } \\
\text { innovation }\end{array}$ \\
\hline & & & OEM/ODM & $\begin{array}{l}\text { Allocated R\&D or system } \\
\text { assembly project }\end{array}$ \\
\hline & \multirow[t]{8}{*}{$\begin{array}{l}\text { Non- } \\
\text { industrial } \\
\text { entity }\end{array}$} & \multirow{8}{*}{$\begin{array}{l}\text { To provide services for the core } \\
\text { manufacturing enterprise during } \\
\text { the open innovation process in } \\
\text { terms of basic knowledge } \\
\text { innovation, application } \\
\text { innovation, management } \\
\text { innovation, talent cultivation, } \\
\text { funding support, etc. }\end{array}$} & Individuals & $\begin{array}{l}\text { Individuals have feedback } \\
\text { or innovative inputs for } \\
\text { the manufacturing } \\
\text { enterprise }\end{array}$ \\
\hline & & & University & $\begin{array}{l}\text { University-firm } \\
\text { collaboration in terms of } \\
\text { science \& research } \\
\text { projects, talent cultivation, } \\
\text { etc. }\end{array}$ \\
\hline & & & $\begin{array}{l}\text { Research } \\
\text { institutes }\end{array}$ & $\begin{array}{l}\text { Technology licensing or } \\
\text { transfer, R\&D } \\
\text { assignments/allocations }\end{array}$ \\
\hline & & & $\begin{array}{l}\text { Innovation } \\
\text { intermediaries }\end{array}$ & $\begin{array}{l}\text { Commercial transactions } \\
\text { in terms of the } \\
\text { distribution of requests } \\
\text { and collection of service } \\
\text { for the enterprise }\end{array}$ \\
\hline & & & Consulting firm & $\begin{array}{l}\text { Consultation services } \\
\text { mainly including } \\
\text { technology and } \\
\text { management innovation }\end{array}$ \\
\hline & & & $\begin{array}{l}\text { Law firms/IP } \\
\text { management } \\
\text { agency }\end{array}$ & $\begin{array}{l}\text { Provide lawsuit dispute/ } \\
\text { intellectual property } \\
\text { rights services as } \\
\text { requested by the core } \\
\text { manufacturing enterprise }\end{array}$ \\
\hline & & & Association & $\begin{array}{l}\text { Standards/regulations } \\
\text { development }\end{array}$ \\
\hline & & & Government & $\begin{array}{l}\text { Approve state key lab, } \\
\text { funding or tax } \\
\text { reductions/exemptions }\end{array}$ \\
\hline
\end{tabular}


hand, they can also adopt third-party innovation intermediaries to introduce more external resources and commercial cooperative options. Accordingly, a manufacturing enterprise can leverage its innovation intermediaries as partners for their innovative solutions/services. In some areas, liaison offices could be set up to absorb global talent, with the aim of solving innovation issues effectively.

Moreover, it does make sense for a manufacturing enterprise to search for potential partners for a new project from among the suppliers and universities it collaborated with on previous projects. For example, suppliers that have revealed innovative technological capacities during the supply process of materials/components in the past, should be considered for the introduction of open innovation. There are some joint scientific and research-funding projects approved by governments or directly undertaken by an enterprise itself, and universities from past partnerships may also be granted an opportunity to contribute to open innovation.

\section{Principles of managing external resources}

Having the correct attitude when dealing with external resources is a priority for any enterprise in its innovation cycle. We herewith give the following two principles:

(i.) Phase-in principle: No barrier should exist when dealing with the introduction of outstanding external resources. In addition, the quantity of qualified external resources candidates must be ensured for the purpose of healthy competition.

(ii.) Phase-out principle: This means that unqualified resources have no space in an open innovation network. In this regard, cost and time spent on these resources are likely to be reduced, which helps innovation efficiency and aids the manufacturing enterprise in reaching its cost-down target during the innovation process.

\section{External resources screening procedures}

External resources have opportunities to contribute to a manufacturing enterprise's innovation project as long as they have the required qualifications. The following procedure is presented to help screen candidates as external resources and to select the qualified resource(s) for a manufacturing enterprise, while excluding any unqualified external resources.

Screening Round I: Set up the criteria regarding the requirements for the external resources' capacities, which are necessary for an innovation project so that the external resources with interest in the innovation project can be organized for initial selection. Hence, the qualified external resources (e.g. the ones with successful backgrounds) are easily identified for further assessment.

Screening Round II: Whether or not an external resource can offer the right services/solutions should be checked at this stage. A successful background does not mean that a particular service/solution is consistent with the manufacturing enterprise's expectations. For example, Foxconn is a worldwide leading Original Equipment Manufacturer (ODM), especially for assembling systems; however, it lacks expertise in the design and manufacturing of certain electronic components. For instance, Foxconn is the system assembler of Xiaomi's smartphone Mi Note, featuring 
a 5.7" FHD display; however, the display panel, camera module, and application processor are developed and supplied by Japan Display Inc. (JDI), Primax and Qualcomm respectively, and Xiaomi contracts them for these resources rather than Foxconn during the planning and design stage of the smartphone development.

Screening Round III: The next stage involves the performance evaluation procedure, in which the external resources will have direct discussions with the manufacturing enterprise about the detailed requirements. Only those external resources possessing the correct and applicable solutions can proceed to this stage. At this stage, various departments of the manufacturing enterprise, including marketing, $R \& D$, procurement and production will gather to carry out the comprehensive appraisal work.

Screening Round IV: This is the price and volume bidding stage. Generally, the price an external resource charges will relate to the volume it must supply to the manufacturing enterprise. For example, if the manufacturing enterprise only needs to purchase a small batch of components from its strategic suppliers, the price would be higher than if a larger volume of components is requested. Additionally, some additional conditions that might include quality assurance and profit and risk sharing would be discussed at this stage, to pave the way for the contract signing later on.

The selection of the external resources will be decided at this stage, after the above procedures have been completed without incident. All the terms, including the scope, obligations, deliverables, and payment terms should be listed in the contract to make the collaboration legal.

According to the above principles, those external resources ruled out by the external resource screening mechanism during the above competition and bidding stages will still have opportunities for future access to the loop on the condition that they make necessary modifications, while the selected external resources would face challenges from other candidates. This indicates that the external resources rotate in a dynamic process using this mechanism. Therefore, for the external resources, there exists concurrent optimization work to establish a self-rotating cycle. This indicates that the external resources with qualified capacities, including successful experience, desirable solutions, competitive service performances and cost efficiency combined with production volume warranties, could eventually be filtered out by this procedure.

\section{General mechanism for collaborating with selected external resources}

Asymmetric information is very likely to occur when a manufacturing enterprise interacts with other external resources. Asymmetric information refers to situations where two parties to a potential transaction do not have the same information (Feinstein 1995). The presence of asymmetric information often leads to an adverse selection of partners in an open innovation activity, which in turn has certain effects when making well-informed decisions. Therefore, it is necessary to consider what effective measures are needed for the management of external resources in order to achieve the expected results. The following general mechanisms are proposed to deal with the presence of asymmetric information, and facilitate the cooperation between the manufacturing enterprise and its external resources:

(i.) Global talent 
In order to have qualified resources participating in the open innovation process rather than staying in the traditional resources loop, it is essential for a manufacturing enterprise to create a mechanism in which the qualified external resources will have no barriers to their bidding and introduction into the open innovation activities. Moreover, it is unwise to only choose local resources that are near the manufacturing enterprise; rather, more globalized resources should also have a fair opportunity and access to the open innovation process. In this case, a manufacturing enterprise should have enough external resources candidates for evaluation, allowing it to recruit the best resource(s). In addition, the interaction methods between a manufacturing enterprise and its external resources need to be diversified. Networking tools can be utilized to pave the way for in-time communication during the bidding stages, especially for those external resources dispersed around the world, and for whom it is sometimes not convenient, or easy, to participate in face-to-face meetings.

(ii.) Participation constraints

Now that the qualified external resources have been recruited, it is necessary for them to be able to operate in a positive environment so that the external resources can yield the expected deliverables. Normally, a contract or agreement is assumed to define the mutual benefits, as well as the responsibilities, between a manufacturing enterprise and its external resources. Both sides should jointly carry out the collaborative innovation project under legal circumstances, as this is essential for 1) coordinating the objectives and strategies of both sides, 2) controlling the milestones of the project, 3) jointly handling risks, and 4) sharing profits from the project. However, it is unwise to have incoming external resources in a location that is so out of reach that they do things independently, and are very far away from the manufacturing enterprise's oversight and expectaions. We call this "if in, then do it well;" and in this regard, an open innovation team needs to be organized effectively.

(iii.) Incentive compatibility

Incoming external resources are members of the open innovation organization; it is impossible to achieve substantial innovation results during the process of collaborative innovation regardless of what they think, or what they lack. A manufacturing enterprise will not only utilize strategic supplier resources in terms of their appraisal and rating, but will also improve their capabilities to reach a sustainable cooperative relationship. More importantly, suitable incentive measures, in terms of profit sharing commissions, also play a vital role in encouraging them to devote their energies proactively.

Providing the best experiences for users is the core pursuit of a collaborative innovation between a manufacturing enterprise and its external resources. Consequently, further measures should be developed to stimulate their innovative inputs in terms of the incentive compatibilities. For example, a manufacturing enterprise drives strategic suppliers to put forward a technical solution based on their product competitiveness, which means that the manufacturing enterprise gives a commitment to the strategic suppliers in terms of its order size. Reversely, the strategic suppliers contribute greatly to technological innovation by relying on the comprehensive innovative capabilities from their $R \& D$, production and quality 
assurance departments. Obviously, a manufacturing enterprise could get more benefits from this "big-to-big" collaboration, such as short "time-to-market" of a new innovative product, low sourcing prices for the materials/modules needed, etc. Under these circumstances, it is necessary for the manufacturing enterprise to offer incentive measures to inspire the strategic suppliers in the open innovation collaboration. For example, when strategic suppliers achieve or surpass set project KPIs (Key Performance Indices) including cost reductions, yield rate increase etc., they should be given additional allowances or profit sharing by the manufacturing enterprise. Moreover, strategic suppliers of good standing could have access to more innovation projects. Strategic suppliers with outstanding contributions may also enjoy the renewal of cooperation agreements for forthcoming innovation projects, allowing them to bring in more profit during these projects.

(iv.) Dynamic optimization

Naturally, fixed external resources are rarely utilized by a manufacturing enterprise during open innovation cycles. A manufacturing enterprise needs to develop certain mechanisms to effectively manage the performance of its external resources. For example, regular assessments or capacity ranking methods could be used to push the external resources to improve their technological innovation abilities. External resources are encouraged to proactively cooperate with manufacturing enterprises to better satisfy end users' demands. Meanwhile, manufacturing enterprises may gradually cultivate strategic external resources, in conjunction with their strategies. In this regard, both sides could have more sustainable cooperation, and strategic external resources could manage the upstream external resources accordingly, which may reduce the redundant coordination work between a manufacturing enterprise and its other external resources, and accelerate the collaboration's innovation steps.

Consequently, a dynamic optimization mechanism could help rule out resources that were previously qualified but are now un-qualified; on the other hand, external resources with qualifications but that are outside the innovation loop due to the comprehensive assessments will still have chances to qualify themselves, and replace existing resources after making the necessary improvements. In this sense, the dynamic operation of the external resources could be realized to boost sustainable open innovations. When there is more than just one competitive solution in the market, or the external resources in a collaboration do not make the necessary improvements within the allocated time, the manufacturing enterprise should still have the right to choose better external resources. Therefore, the external resources operate in a dynamic optimization cycle, but only if the external resources continuously improve their innovative capabilities so that they can then be accepted by the manufacturing enterprise for sustainable cooperation. Otherwise, other better candidates will replace un-qualified or uncompetitive external resources in the innovation resource loop.

\section{A business collaboration model of the TOI}

For the purpose of this paper, we have divided the TOI into two aspects: basic research innovation and application innovation. The former focuses on prospective and mid-tolong term innovative technological research, while application innovation describes 
product development to fulfill the market requirements in the near future. Normally, basic innovation is supervised by the corporate research \& development center in charge of the general technology $R \& D$, standardization and intellectual property management, which is regarded as a corporate and strategic level department. An application innovation is closer to a marketable product and may work better under the management of a product research \& development institute. However, both aspects of the TOI should be rationally coordinated and combined, and share the external resources to pursue the maximum value for the TOI.

As per the above classification, a business collaboration model focusing on a new product R\&D phase is given (shown in Fig. 2), in which the basic research innovations and application innovations are managed in the product R\&D process. This model can be a reference for an enterprise to coordinate the phasing-in and phasing-out of external resources of the TOI. All inputs/outputs via external/internal collaborations in the business model will be evaluated dynamically according to the nature of the innovation project; the result of such evaluations will lead to "Go/No Go" decisions on how to proceed with the next step. For example, "Go" indicates that the corresponding activity will continue as it is, or will continue but with considerations, while "No Go" would indicate that the input/output of the activity is not in line with the evaluation criteria, and should be suspended or should cease to release resources. To cultivate knowledge management during the open innovation process, such decisions and follow-up actions should be recorded and reflected in the forthcoming strategy and plan.

\section{A case study}

Haier Group is well regarded as a representative for Chinese manufacturing enterprises in actively implementing open innovation strategies, particularly in that Haier integrates global resources to enhance its technology innovation. Beside, one of the authors

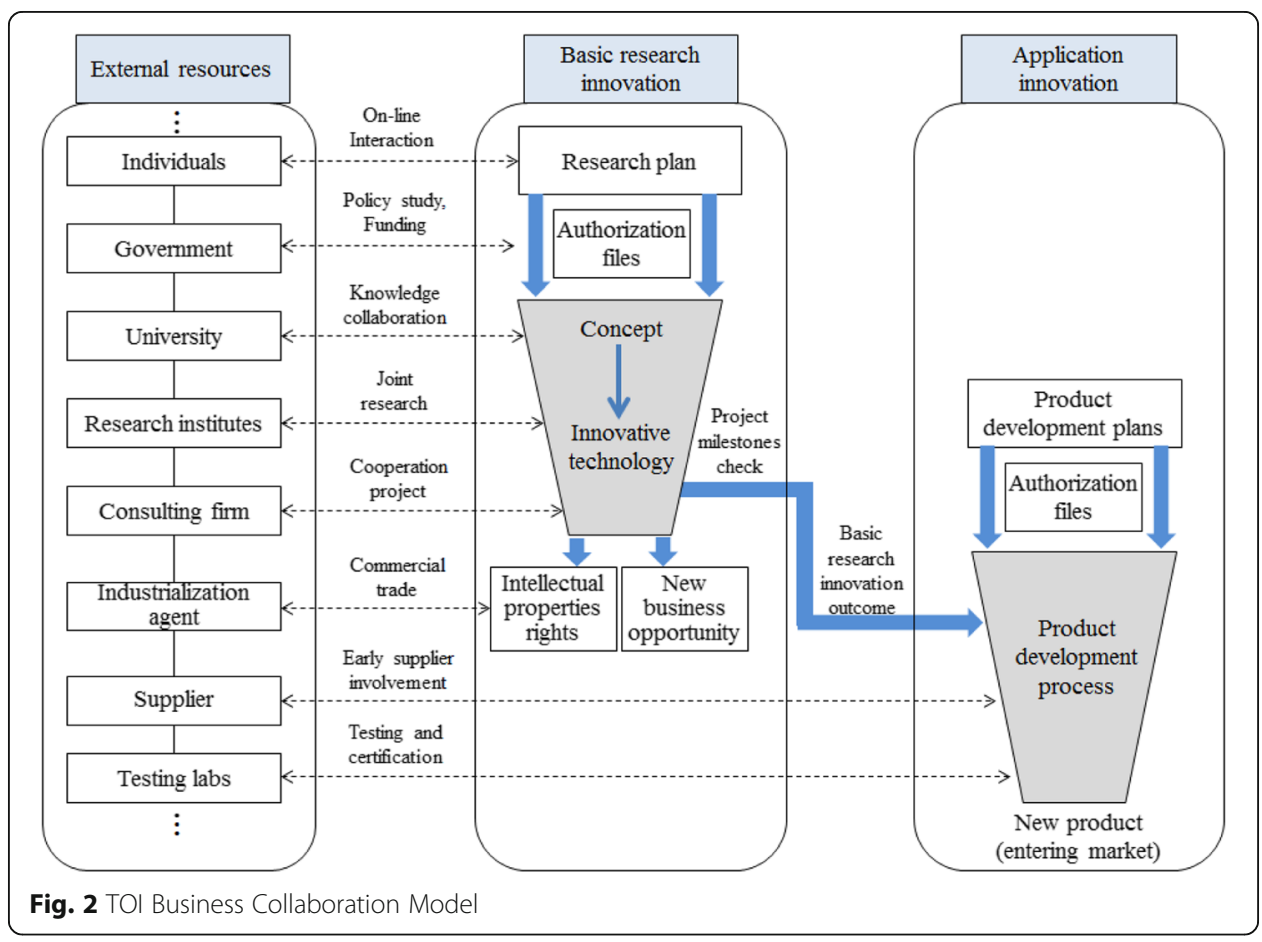


of this paper previously worked for Haier Group for many years, largely engaged with the R\&D and implementation portions of its open innovation strategy. Thus, Haier Group can be considered as an ideal object for case study. In this paper, the TOI practice implemented by Haier Group is utilized to further illustrate the feasibility of the theory presented.

Established in 1984, the Haier Group is a global leader in consumer electronics and was the leading home appliance brand, as ranked by Euromonitor International 2014. With its assortment of products diversified towards the global markets, Haier has been seeking more innovation potential to boost its manufacturing enterprise's development. Given limited internal resources, to say nothing of the severe competition in the market, it is impossible for Haier alone to provide products/solutions for all its customers. Consequently, Haier set a target to transform itself from a traditional manufacturer into a comprehensive service provider, in which the manufacturing enterprise's innovation strategy is characterized by the saying, "the world is Haier's R\&D department."

In our observation, we found that Haier is strengthening its R\&D capacities not only through its internal R\&D investments, but also with its external collaborations. As per the above situation, an Overall Open Innovation (OOI) strategy has been applied and implemented by the Haier Group since the beginning of 2013, and the TOI of Haier has since become the benchmark for China's home appliance industries. As far as we understand, Haier carried out the following TOI practices:

(1) Reconstruct its R\&D system: Previously, there was no clear distinction between technology $R \& D$ and the product $R \& D$ departments in Haier. In this case, Haier's corporate $R \& D$ center had some overlapping functions with its $R \& D$ institutes regarding product lines, including refrigerators, washing machines, air-conditioner units, etc., which led to several disputes and quarrels. With respect to its open innovation, the corporate $R \& D$ center was put in charge of the generic technology R\&D, standardization and intellectual property management, etc., while concrete products that entered the market were put within the scope of the product development institutes. More importantly, an open innovation platform (discussed hereunder) was created and operated by an open innovation operations team from the corporate $R \& D$ center, and this team targeted the integration of global external resources to satisfy the internal innovation requirements. Both of the above two divisions utilized external resources via the open innovation operations team, and the technology innovation transferring mechanism was used to link them. During the process of entering the global market, Haier paid a great deal of attention to its localization strategy, and further refined the R\&D system built into its global networks. Currently, Haier has its corporate R\&D center located in Qingdao, China, where it is in charge of the other $15 \mathrm{R} \& D$ institutes distributed around the world (shown in Fig. 3). In recent years, Haier successively merged with Sanyo (a Japanese brand) and Fisher \& Paykel (from New Zealand) to strengthen its brand influence in the home appliances industry. During its globalization process, Haier is making great efforts to search for useful external resources. External sources are both an indispensable part of Haier's globalization, from its marketing to manufacturing, down to its global $R \& D$, and are vital pillars to improve Haier's global branding influence. 


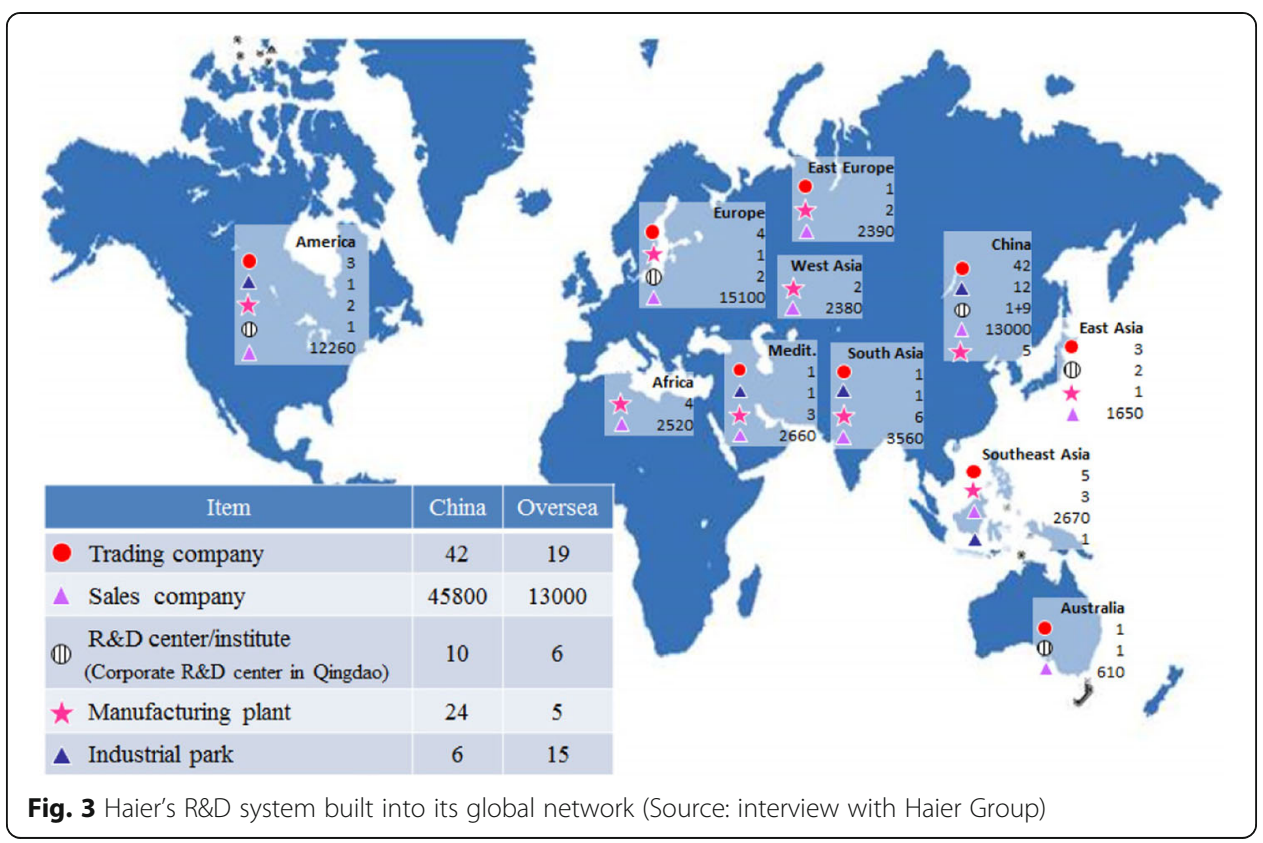

(2) External resource integration in open innovation: During the process of implementing its open innovation strategy, Haier utilized the relevant mechanisms mentioned in Open innovation business model section (on how to manage external resources), rather than rigidly negotiating with external resources case by case. The external resources were managed dynamically, which demonstrates the special role of these mechanisms in a self-rotating optimization cycle (Fig. 1). To identify the nature of the external resources, Haier classified them respectively into industrial (suppliers, partner enterprises, testing labs, etc.) and non-industrial (individuals, universities, research institutes, etc.) entities; hence the corresponding external resources with appropriate expertise could be integrated in order to match Haier's requirements for technological innovation. Moreover, Haier adopted the "global talents" mechanism to ensure that qualified resources, without boundary limits, could be absorbed into the innovation process under a controllable system, namely the "participation constraint", while unqualified resources were excluded from the innovation activities by means of "dynamic optimization". According to the concrete requirements of technology innovation, some of the selected external resources (such as the strategic suppliers) could be stimulated by an "incentive compatibility" to yield extraordinary performances. In this regard, the qualified resources could effectively contribute to Haier's basic research innovation, in combination with its product development innovation.

In our study, the following typical innovative products of Haier Group were developed by the TOI (shown in Table 2), in which the corresponding selected external resources are embedded in conjunction with their contributions.

(3) TOI platform operation. To facilitate the interaction and collaboration with external resources, Haier set up a TOI platform (hope.haier.com, shown in Fig. 4) with networking tools, which aims to provide a community for the public. The TOI platform has also proven to be more efficient and accessible for external resources that wish to join in the TOI activities. Our observations revealed that 
Table 2 Haier's typical innovative products developed by TOI

\begin{tabular}{|c|c|c|c|c|c|}
\hline No. & $\begin{array}{l}\text { Innovative } \\
\text { product }\end{array}$ & Description & $\begin{array}{l}\text { Major external } \\
\text { resources }\end{array}$ & $\begin{array}{l}\text { Contributions of } \\
\text { external resources }\end{array}$ & Remarks \\
\hline \multirow[t]{2}{*}{1} & Wireless TV & $\begin{array}{l}\text { No cables; TV } \\
\text { operated through } \\
\text { a wireless } \\
\text { charging function }\end{array}$ & $\begin{array}{l}\text { MIT (University, } \\
\text { USA) }\end{array}$ & $\begin{array}{l}\text { Provided wireless } \\
\text { technology and } \\
\text { solutions with } \\
\text { patents for Haier }\end{array}$ & $\begin{array}{l}\text { The marketing } \\
\text { requirements } \\
\text { surveying the } \\
\text { combined } \\
\text { commercialization } \\
\text { of wireless TV was } \\
\text { executed by Haier }\end{array}$ \\
\hline & & & $\begin{array}{l}\text { Wireless Power } \\
\text { Consortium } \\
\text { (WPC, standard } \\
\text { consortium) }\end{array}$ & $\begin{array}{l}\text { Provided a } \\
\text { platform for Haier } \\
\text { and other } \\
\text { members to } \\
\text { develop standards } \\
\text { for such a product }\end{array}$ & $\begin{array}{l}\text { Acquired WPC } \\
\text { certificate (Qi } \\
\text { logo) to facilitate } \\
\text { future market } \\
\text { entry issues }\end{array}$ \\
\hline \multirow[t]{3}{*}{2} & $\begin{array}{l}\text { Waterless } \\
\text { washing } \\
\text { machine }\end{array}$ & $\begin{array}{l}\text { Uses new washing } \\
\text { media (micro ball) } \\
\text { instead of water; } \\
\text { saves water } \\
\text { resources and } \\
\text { protects the } \\
\text { environment. }\end{array}$ & $\begin{array}{l}\text { DOW (Strategic } \\
\text { supplier, USA) }\end{array}$ & $\begin{array}{l}\text { System design of } \\
\text { waterless washing } \\
\text { machine, and also } \\
\text { jointly developed } \\
\text { the new washing } \\
\text { media with Bayer }\end{array}$ & $\begin{array}{l}\text { P\&G also joined in } \\
\text { the development } \\
\text { and provided } \\
\text { solutions for } \\
\text { increasing the } \\
\text { washing capacity } \\
\text { of the micro ball }\end{array}$ \\
\hline & & & $\begin{array}{l}\text { Bayer (Strategic } \\
\text { supplier, Germany) }\end{array}$ & $\begin{array}{l}\text { In charge of the } \\
\text { development and } \\
\text { supply of the } \\
\text { micro ball }\end{array}$ & $\begin{array}{l}3 \text { M (USA) also } \\
\text { sent samples for } \\
\text { Haier's } \\
\text { consideration }\end{array}$ \\
\hline & & & $\begin{array}{l}\text { China Academy of } \\
\text { Science (CAS, } \\
\text { Research institute) }\end{array}$ & $\begin{array}{l}\text { Mechanical design } \\
\text { and mechanical } \\
\text { analysis of the } \\
\text { washing machine }\end{array}$ & $\begin{array}{l}\text { CAS is the leading } \\
\text { research institute } \\
\text { in China }\end{array}$ \\
\hline \multirow[t]{2}{*}{3} & $\begin{array}{l}\text { Networking } \\
\text { refrigerator }\end{array}$ & $\begin{array}{l}\text { The product was } \\
\text { designed not only } \\
\text { as a storage } \\
\text { compartment } \\
\text { but as a } \\
\text { communications } \\
\text { terminal to } \\
\text { connect to other } \\
\text { home appliances }\end{array}$ & $\begin{array}{l}\text { International } \\
\text { Electrotechnical } \\
\text { Commission } \\
\text { (IEC, Standard } \\
\text { association) }\end{array}$ & $\begin{array}{l}\text { Provided a } \\
\text { platform for Haier } \\
\text { and other } \\
\text { members to } \\
\text { develop } \\
\text { international } \\
\text { product } \\
\text { specifications } \\
\text { combining } \\
\text { communications } \\
\text { standards }\end{array}$ & $\begin{array}{l}\text { There is a special } \\
\text { working group } \\
\text { under the IEC } \\
\text { Standard } \\
\text { Management } \\
\text { Body mainly in } \\
\text { charge of smart } \\
\text { home standards }\end{array}$ \\
\hline & & & $\begin{array}{l}\text { iTopHome } \\
\text { (Networking } \\
\text { appliances } \\
\text { industry alliance, } \\
\text { China) }\end{array}$ & $\begin{array}{l}\text { Integrated supply } \\
\text { chains for } \\
\text { networking } \\
\text { refrigerators to } \\
\text { develop China's } \\
\text { national standards } \\
\text { and promote its } \\
\text { commercialization }\end{array}$ & $\begin{array}{l}\text { The outcomes of } \\
\text { iTopHome } \\
\text { concerning } \\
\text { standards are in } \\
\text { line with the } \\
\text { requirements of } \\
\text { IEC standards }\end{array}$ \\
\hline
\end{tabular}

more than $60 \%$ of the TOI ideas and solutions at Haier originated from the TOI platform since its launch in 2010.

The working process of the TOI platform is as follows:

Step 1: Register one's ID and wait for approval.

Step 2: Haier classifies and ranks the incoming external resources, then approves relevant rights with different levels of access to its project database. For instance, ordinary customers are only allowed access for posting ideas to the profiles of the ongoing projects, while those with outstanding backgrounds and relevant solutions could gain more access, allowing them to provide ideas/solutions and greater content related to the ongoing projects. 


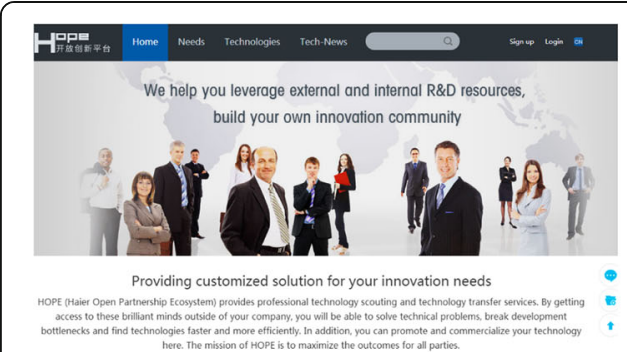

a Welcome page
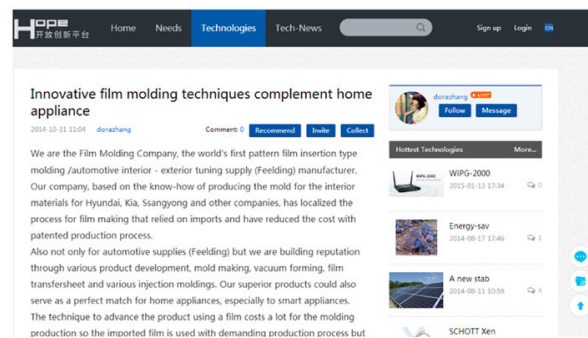

c Inputs from external resource

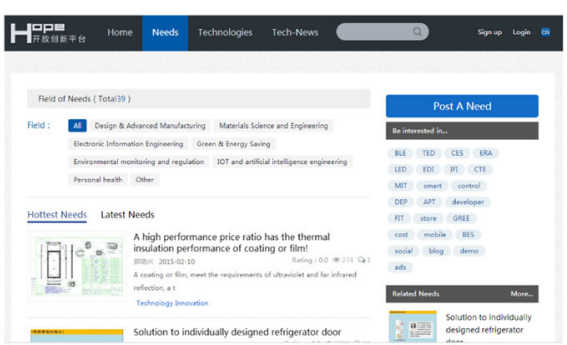

b Market requirements display

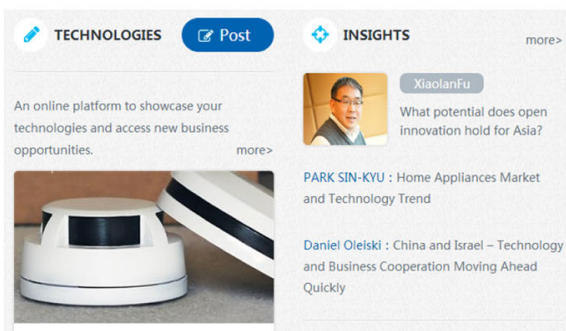

d Interaction space

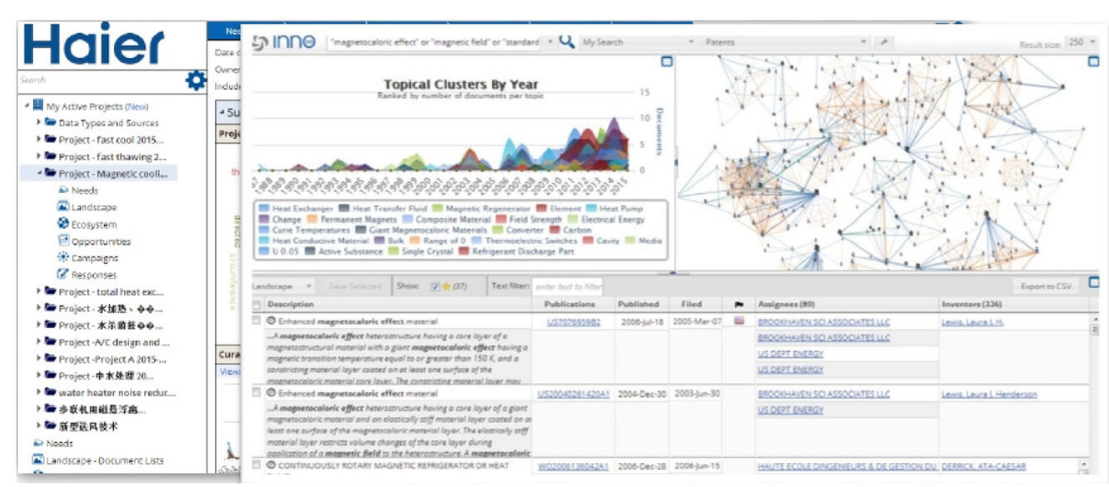

e Project management module of Haier's technology open innovation platform (linked with InnoCentive platform)

Fig. 4 Haier's technology open innovation platform webpages' showcase. (Sources: a), b), c) and d) cited from hope.haier.com; e) Interview with Haier Group)

Step 3: External resources present relevant ideas/solutions in conjunction with innovation requirements posted by Haier.

Step 4: The relevant department will handle the ideas/solutions. If an idea/ solution is accepted, the external resource can move forward to the next stage; conversely, the idea/solution could be refined for the forthcoming proposal. Meanwhile, ideas/solutions presented by external resources will be stored in the innovation knowledge database.

Step 5: Negotiations and signing of an agreement to formalize the cooperation. Step 6: Execution of plan.

Since the release and operation of the technology open innovation platform at the beginning of 2013, Haier Group has increasingly intensified its intimacy with external resources, and the following figures showcase their achievements in the implementation of this platform.

(i.) Participants or end-users/clients: 1,780,000

(ii.) Registered external resources: 120,000

a) Individuals: 108,500 
b) Universities: 230

c) Partner research institutes: 417

d) Suppliers: 5280

e) Industrialization agents: 1331

(iii) Total innovative proposals: 5800

(iv) Finished/ongoing projects: 319

(4) Refining the interface between the R\&D system and the supply chain system. Empirically, whether the outcome of a TOI is successfully executed or not depends on the internal collaboration of the manufacturing enterprise. However, a marketable new product can be produced only if the interface between the R\&D system and the supply chain system can be refined to some extent. Accordingly, delegates from the supply chain system join in the open innovation's organization and prepare in advance for the forthcoming sourcing and procurement work. Furthermore, there is another corresponding system called the "module supplier network" (l.ihaier.com), which was developed to attract global suppliers to deliver modules or components in conjunction with the outcomes of open innovations.

(5) The novelty of the proposed open innovation strategy. From the theoretical characteristics and the empirical case study, it can be argued that the proposed open innovation strategy combining mechanism is novel, because it is operational and capable of managing external resources efficiently and effectively.

\section{Conclusion}

Open innovation plays an increasingly vital role in supporting a manufacturing enterprise's continued development. In order to integrate external resources more efficiently, it is essential to classify the resources categories and build a relevant mechanism, under which the optimization of the external resources can be executed in a self-rotating innovation cycle.

Moreover, an overall open innovation business model is presented, to identify the logical relationship between the manufacturing enterprise, and its end-users and external resources. Additionally, a TOI is specifically discussed in this paper, in which the classification of the external resources, and an external resources screening mechanism are analyzed, and shown to help in selecting qualified resources and excluding unqualified resources from the business model. The outcome could be a reference for manufacturing enterprises to coordinate the phasing-in and phasing-out of external resources during the TOI process. In addition, our paper indicates the feasibility of the model proposed in this paper with the Haier Group TOI case study. Therefore, this paper has provided a new model for open innovation, enabling the management of external resources, which is missing in the current literature. The proposed open innovation strategy model can be useful in other enterprises for efficient management of external resources and enhanced performance.

There are some limitations to be further studied including: (1) the authors focus on the development of a generic mechanism framework; and it would be worthwhile to consider a particular mechanism suitable for the management of a specific external resource; (2) there is a need to explore more case studies from a variety of industrial backgrounds. In this regard, the proposed open innovation strategy combined with the generic mechanism framework could be further verified and may be of reference for other enterprises. 


\section{Endnote}

${ }^{1}$ A strategic supplier is not only capable of supplying materials or components based on demand, but participates in the open innovation activities depending on their competitive technology. Generally, a strategic supplier's important contribution to a manufacturing enterprise's innovation is in terms of its early supplier involvement with the manufacturing enterprise's product research and development process.

\section{Acknowledgements}

This study is supported by the China Social Science Foundation (15BGL007), and the authors herewith express their appreciation for its support. The authors thank the valuable comments and suggestions from the annonimous reviewers, and acknowledge the editorial assistance in revising this paper.

\section{Authors' contributions}

Both authors read and approved the final manuscript.

\section{Competing interests}

The authors declare that they have no competing interests.

Received: 30 September 2016 Accepted: 9 February 2017

Published online: 05 June 2017

\section{References}

Cachon, G. P., \& Lariviere, M. A. (1999a). Capacity allocation using past sales: when to "turn-and-earn". Management Science, 45(5), 685-703.

Cachon, G. P., \& Lariviere, M. A. (1999b). Capacity choice and allocation: Strategic behavior and supply chain performance. Management Science, 45(8), 1091-1108.

Chesbrough, H. (2003). Open innovation: How companies actually do it. Harvard Business Review, 81(7), 12-14.

Chesbrough, H. (2007). Why companies should have open business models? MIT Sloan Management Review, 48(2), 22-28.

Chesbrough, H., Vanhaverbeke, W., \& West, J. (2006). Open innovation: researching a new paradigm. Oxford: Oxford University Press.

Chesbrough, H., Sohyeong, K., \& Agogino, A. (2014). Chez panisse: building an open innovation ecosystem. California Management Review, 56(4), 144-171.

Dougherty, D. (1992). A practice-centered model of organizational renewal through product innovation. Strategic Management Journal, 13(S1), 77-92.

Eisenhardt, K. M., \& Martin, J. A. (2000). Dynamic capabilities: what are they? Strategic Management Journal, 21(10/11), $1105-1121$.

Erden, Z., Von Krogh, G., \& Kim, S. (2012). Knowledge sharing in an online community of volunteers: the role of community munificence. European Management Review, 9(4), 213-227.

Etzkowita, H. (2008). The triple helix: University-industry-government innovation in action. London and New York: Routledge.

Feinstein, J. S. (1995). Asymmetric information, accounting manipulations, and partnerships. Journal of Economic Behavior \& Organization, 26(1), 49-73.

Gambardella, A., \& Panico, C. (2014). On the management of open innovation. Research Policy, 43(5), 903-913.

Granovetter, M. (1985). Economic action and social structure: the problem of embeddedness. American Journal of Sociology, 91(3), 481-510.

Huston, L., \& Sakkab, N. (2006). Connect and develop: inside Procter \& Gamble's new model for innovation. Harvard Business Review, 84(3), 58-66.

IBM Press Room. (2008). IBM opens global supply chain innovation center in China. Available online at, http://www-03. ibm.com/press/us/en/pressrelease/23677.wss.

Ivascu, L., Cirjaliu, B., \& Draghici, A. (2016). Business Model for the University-industry collaboration in open innovation. Procedia Economics and Finance, 39, 674-678.

Laffont, J.-J., \& Tirole, J. (1988). The dynamics of incentive contracts. Econometrica, 56(5), 1153-1175.

Laffont, J.-J., \& Tirole, J. (1993). A theory of incentives in procurement and regulation. Cambridge: MIT Press.

Leydesdorff, L. (2003). The mutual information of university-industry-government relations: An indicator of the triple helix dynamics. Scientometrics, 58(2), 445-467.

Li, W., Chang, J., \& Wang, M. J. 李万，常静，王敏杰. (2014) Innovation 3.0 and innovation ecosystem (创新3.0与创新生 态系统).科学学研究. Studies in Science of Science, 32(12): 1761-1770.

Mikkola, J. H., \& Skjøtt-Larsen, T. (2006). Platform management: Implications for new product development and supply chain management. European Business Review, 18(3), 214-230.

Minshall, T., Mortara, L., \& Ulrichsen, T. (2016). Centre for Technology Management working paper series. Cambridge: University of Cambridge.

Moore, J. F. (1993). Predators and prey: A new ecology of competition. Harvard Business Review, 71(3), 75-86. Muhdi, L. (2011). Open innovation and collaboration for innovations. Contemporary Accounting Research, 27(2), 345-345.

Nakagaki, P., Aber, J., \& Fetterhoff, T. (2012). The challenges in implementing open innovation in a global innovationdriven corporation. Research-Technology Management, 55(4), 32-38.

Nambisan, S., \& Sawhney, M. (2007). A buyer's guide to the innovation bazaar. Harvard Business Review, 85(6), 109-118. Nelli, T. (2013). Extending open innovation throughout the value chain by small and medium-sized manufacturers. International Small Business Journal, 31(3), 256-274. 
Pfeffer, J. (1987). A resource dependence perspective on interorganizational relations. In M. S. Mizruchi \& M. Schwartz (Eds.), Intercorporate relations: the structural analysis of business (pp. 22-55). Cambridge: Cambridge University Press. Pfeffer, J., \& Salancik, G. R. (1978). The external control of organizations: a resource dependence perspective. New York: Harper \& Row.

Rothaermel, F. T., \& Alexandre, M. T. (2009). Ambidexterity in technology sourcing: the moderating role of absorptive capacity. Organization Science, 20(4), 759-780.

Sakamoto, AR., Villar, CB., \& Martins, ME. (2012) Open innovation and collaborative network in supply chain: the case of open IPTV forum. IGI Global, 232-247. doi:10.4018/978-1-61350-341-6.ch014.

Serrono, V., \& Fischer, T. (2007). Collaborative innovation in ubiquitous systems. International Manufacturing, 18, 599-615.

Sivadas, E., \& Dwyer, F. (2000). An examination of organizational factors influencing new product succes in internal and alliance-based processes. Journal of Marketing, 64(1), 31-49.

Todorova, G., \& Durisin, B. (2007). Absorptive capacity: Valuing a reconceptualization. Academy of Management Review, 32(3), 774-786.

Ulrich, D., \& Barney, J. B. (1984). Perspectives in organizations: resource dependence, efficiency, and population. Academy of Management Review, 9(3), 471-481.

West, J., Vanhaverbeke, W., \& Chesbrough, H. (2006). Open innovation: a research agenda. In H. Chesbrough, W. Vanhaverbeke, \& J. West (Eds.), Open innovation: researching a new paradigm (pp. 285-307). Oxford: Oxford University Press.

Williamson, P. J., \& Meyer, A. D. (2012). Ecosystem advantage. California Management Review, 55(1), 24-46.

Zhang, Z. Y., \& Chen, J. (2008). The composition, characteristics and management of enterprises' innovation resource based on open innovation pattern. Science of Science and Management of S.\& T, 29(11), 61-65.

Zhao, Y., \& Lavin, M. (2012). An empirical study of knowledge transfer in working relationships with suppliers in new product development. International Journal of Innovation Management, 16(2), 1-26.

Zhou, K. Z., \& Wu, F. (2010). Technological capability, strategic flexibility and product innovation. Strategic Management Journal, 31(5), 547-561.

Submit your manuscript to a SpringerOpen ${ }^{\circ}$ journal and benefit from:

- Convenient online submission

- Rigorous peer review

- Open access: articles freely available online

- High visibility within the field

- Retaining the copyright to your article

Submit your next manuscript at $>$ springeropen.com 